\title{
Prognostic value of Th17 cells in acute leukemia
}

\author{
Nashwa Khairat Abousamra • Manal Salah El-Din • \\ Randah Helal
}

Received: 26 July 2013/Accepted: 16 September 2013/Published online: 2 October 2013

(C) The Author(s) 2013. This article is published with open access at Springerlink.com

\begin{abstract}
Th17 cells and their effector cytokines have emerged as important mediators in inflammatory and autoimmune diseases and serve as an ambitious field in current immunology research. Recent studies suggest a potential impact of Th17 cells on solid tumors but relatively little is known about their contribution in hematological malignancies. The current study was designed to investigate the possible involvement and clinical significance of circulating Th17 cells in acute leukemia. Flow cytometry was used to analyze percentages of Th17 cells in peripheral blood mononuclear cells from 93 acute leukemia patients (ALL, $n=30$; AML, $n=63$ ) and 40 healthy volunteers. Serum levels of IL-17 and IL-21 were measured using enzyme-linked immunosorbent assay. Circulating Th17 cells were increased in patients with acute leukemia $(2.88 \pm 0.65 \%$ and $2.90 \pm 0.57 \%$ in ALL and AML patients, respectively) and were significantly higher than in healthy controls $(1.10 \pm 0.28 \% ; \quad P=0.001)$. Furthermore, pretreatment Th17 cells were reduced significantly in patients who achieved complete remission after induction therapy $(2.25 \pm 0.44 \%$ and $1.63 \pm 0.27 \%$ in ALL and AML patients, respectively, $P<0.0001$ ). Serum levels of IL-17 and IL-21 were significantly
\end{abstract}

N. K. Abousamra ( $\square)$

Department of Clinical Pathology, Hematology Unit, Faculty of Medicine (35516), Mansoura University, Mansoura, Egypt

e-mail: abosamrana@yahoo.com

M. Salah El-Din

Department of Medical Oncology, Oncology Center, Mansoura University, Mansoura, Egypt

R. Helal

Department of Public Health and Community Medicine, Faculty of Medicine, Mansoura University, Mansoura, Egypt elevated in acute leukemia patients. Kaplan-Meier curves revealed a significantly longer overall survival in patients with high Th17 levels $(P=0.029$ and $P=0.027$ for ALL and AML, respectively). In the multivariate analysis, Th17 cells retained statistical significance for overall survival in patients with ALL (OR 0.331; $P=0.043$ ) and AML (OR $0.489 ; P=0.032$ ). These results strongly suggest Th17 cells as a powerful new prognostic determinant which could serve as a potential therapeutic target to modulate anti-tumor response in acute leukemia patients.

Keywords Th17 cells · Acute leukemia - IL-17 . IL-21

\section{Introduction}

Adaptive immunity plays a crucial role in tumor immunosurveillance $[1,2]$. It has been shown that tumor-infiltrating effector $\mathrm{T}$ cells are associated with improved prognoses in multiple human cancers [3-5], whereas tumor-infiltrating regulatory $\mathrm{T}$ cells $(\mathrm{T}$ reg) are negatively associated with patients' outcome [5, 6].

$\mathrm{T}$ helper 17 (Th17) cells are newly identified effector CD4+ cells [7]. Their discovery has resulted in an explosion of immunological research, and it is now widely accepted that the Th17 subset is an independent lineage of Th cells based on their unique cytokine profile, transcriptional regulation, and biological function [8, 9]. They release their signature cytokine IL17A together with IL17F, IL21, IL22, and IL26 [10]. The identification of Th17 cells not only changes the classical Th1/Th2 paradigm of Th cell differentiation but also markedly facilitates our understanding of human immunity under both physiological and pathological conditions [9]. 
Table 1 Subjects' characteristics

\begin{tabular}{|c|c|c|c|c|c|}
\hline Parameters & \multicolumn{2}{|c|}{$\operatorname{ALL}(n=30)$} & \multicolumn{2}{|c|}{$\operatorname{AML}(n=63)$} & Controls $(n=40)$ \\
\hline \multicolumn{6}{|l|}{ Gender } \\
\hline Male & & $18(60 \%)$ & & $33(52.3 \%)$ & $23(57.5 \%)$ \\
\hline Female & & $12(40 \%)$ & & $30(47.6 \%)$ & $17(42.5 \%)$ \\
\hline \multicolumn{6}{|l|}{ Age } \\
\hline Median (range) & & 31.5 (19-59) & & $48(23-63)$ & $42(20-61)$ \\
\hline \multicolumn{6}{|l|}{ Remission } \\
\hline Yes & $25 / 28$ & $(89.3 \%)$ & $37 / 59$ & $(62.7 \%)$ & \\
\hline No & $3 / 28$ & $(10.7 \%)$ & $22 / 59$ & $(37.3 \%)$ & \\
\hline \multirow[t]{3}{*}{ Cytogenetic abnormalities } & Missing & $10(33.3 \%)$ & Favorable $^{\mathrm{a}}$ & $17(27 \%)$ & \\
\hline & $\mathrm{Ph}-\mathrm{ve}$ & $17(56.7 \%)$ & Intermediate $^{\mathrm{b}}$ & $26(41.3 \%)$ & \\
\hline & $\mathrm{Ph}+\mathrm{ve}$ & $3(10 \%)$ & Adverse $^{c}$ & $20(31.7 \%)$ & \\
\hline
\end{tabular}

${ }^{a}$ Favorable: $t(15 ; 17)(\mathrm{q} 22 ; \mathrm{q} 21), t(8 ; 21)(\mathrm{q} 22 ; \mathrm{q} 22), \operatorname{inv}(16)(\mathrm{p} 13 ; \mathrm{q} 22) / t(16 ; 16)(\mathrm{p} 13 ; \mathrm{q} 22)$

${ }^{\mathrm{b}}$ Intermediate: entities not classified as favorable or adverse

c Adverse: $-5 / 5 q-,-7 / 7 q-$, abn(11q23), or complex karyotype with three or more cytogenetic abnormalities

It has been suggested that Th17 cells were increased in patients with solid tumors [11] but little is known about Th17 cells in hematological malignancies.

IL-17 has pro- and anti-tumor actions [12]. It was suggested that endogenous IL-17 positively impacts on tumor immunity [13]. Th17 cells have also been shown to produce IL-21, a cytokine that can amplify the differentiation of Th17 cells in an autocrine manner as well as control T cell-dependent humoral responses [14, 15]. Increasing evidence suggests an involvement of IL-21 in hematopoietic malignancies [16].

Acute leukemias represent ideal models to assess the impact of cancer on the host immune system as the disease is widely disseminated, so that immune cells in the peripheral blood are in close proximity to the tumor cells. Failure to recognize and eradicate leukemia cells may partly be a result of insufficient immunological activation. Despite the few studies focusing on Th17 cells in acute leukemia, there are controversies with regard to their results $[17,18]$. In this study, we determined the prevalence of circulating Th17 cells and serum concentration of their related cytokines IL-17 and IL-21 in adult acute leukemia patients to evaluate their potential impact on disease outcome.

\section{Subjects and methods}

\section{Patients}

Between May 2010 and December 2012, peripheral blood samples were obtained with informed consent and Institutional Review Board approval from 93 newly diagnosed patients with acute leukemia (63 patients with AML and 30 patients with ALL) and 40 age-matched healthy volunteers. Diagnosis and classification were based on WHO classification [19]. Data describing the study subjects are summarized in Table 1. Response was evaluated after induction therapy in 87/93 patients. Two patients (one patient with ALL and the other with AML) received only supportive care while four patients (one patient with ALL and three patients with AML) died during induction therapy before hematological recovery and were excluded from the response analysis. Patients with T-ALL were excluded from this study because of their low incidence and the induced immune tolerance hypothesized in those patients [20].

\section{Main reagents}

The following anti-human monoclonal antibodies were used: fluorescein isothiocyanate (FITC)-labeled anti-CD4, R-phycoerythrin-cyanine 5 (RPE-CY5)-labeled anti-IL-17A, phycoerythrin (PE)-labeled anti-CD3 (eBioscience, San Diego, USA), and their appropriate isotype controls (Dakocytoformation, Denmark). Fixation and permeabilization of cells were done using Intraprep kits reagent (immunotech, Beckman Coulter, Marseille, France). Phorbol myristate acetate (PMA) and ionomycin were purchased from Sigma, USA. Human IL-17 and IL-21 ELISA kits were purchased from Bender Medsystems, Austria.

Flow cytometric analysis

Peripheral blood mononuclear cells (PBMCs) were isolated by standard Ficoll-Hypaque density centrifugation of heparinized peripheral blood from healthy control subjects and patients before and after induction chemotherapy. PBMCs were cultured in RPMI 1,640 medium that contained 
$100 \mathrm{U} / \mathrm{mL}$ penicillin, $100 \mathrm{U} / \mathrm{mL}$ streptomycin, and $10 \%$ fetal bovine serum. Cell density was adjusted to $2 \times 10^{6}$ cells $/ \mathrm{mL}$. Cells were stimulated by adding $50 \mathrm{ng} / \mathrm{mL}$ PMA, $1 \mu \mathrm{g} / \mathrm{mL}$ ionomycin, and $10 \mu \mathrm{g} / \mathrm{mL}$ BFA to the medium for $5 \mathrm{~h}$ at $37{ }^{\circ} \mathrm{C}$ under $5 \% \mathrm{CO}$. Stimulated cells were centrifuged at $1,200 \mathrm{~g}$ for $7 \mathrm{~min}$ at $10{ }^{\circ} \mathrm{C}$, washed, and then surface stained by incubating cells $\left(1-2 \times 10^{6} / \mathrm{mL}\right)$ for $30 \mathrm{~min}$ at room temperature in the dark with fluorescence-labeled anti-CD3 and anti-CD4. For intracellular staining, cells were subsequently treated with cell fixation and permeabilization reagents following the manufacturer's instructions and then incubated with a fluorescence-labeled antiIL-17A for $30 \mathrm{~min}$ at $4{ }^{\circ} \mathrm{C}$. Cells were resuspended in PBS and analyzed using the EPICS XL flow cytometer (Coulter Electronic, Fl, USA). Appropriate isotypic controls were used to determine specific binding for each fluorescent channel. After gating on CD3+ CD4+ cells, Th17 cells were defined as the percentage of IL-17+ cells.

Enzyme-linked immunosorbent assay (ELISA)

The serum of patients and healthy volunteers was analyzed for the Th17-related cytokines IL-17 and IL-21 using ELISA, following the manufacturer's instructions. All samples were measured in duplicate.

\section{Statistical analysis}

Data were analyzed using SPSS, version 16 . K-S test was used to test the normality of data. Descriptive analysis of the collected data was done with calculation of frequencies, median, and range. In normally distributed variables, student's $t$ test, paired $t$ test, and one-way ANOVA were used to compare the means between different groups, as appropriate. Correlation between Th17 and other parameters was examined by Spearman's correlation coefficient. Overall survival was measured from the time of diagnosis to death or last observation. It was calculated and represented by Kaplan-Meier plots and the log-rank test, which was also used to evaluate the possible associations between OS and each risk factor singly. All the parameters of significant value in univariate analysis were entered in a stepwise multivariate Cox proportional hazard model. $P \leq 0.05$ was chosen as the level of statistical significance.

\section{Results}

Increased circulating Th17 cells in acute leukemia patients

We investigated levels of circulating Th17 cells in untreated AML and ALL patients as well as in healthy controls. Representative plots showed that circulating Th17 cells were increased in untreated patients $(2.88 \pm 0.65 \%$ and $2.90 \pm 0.57 \%$ in ALL and AML patients, respectively) compared to healthy volunteers $(1.10 \pm 0.28 \%)$, where the difference was statistically significant $(P<0.001)$ (Fig. 1). However, difference in circulating Th17 cells between ALL and AML patients before treatment was not statistically significant $(P=0.862)$.

Level of circulating Th17 cells differs according to therapeutic response in acute leukemia patients

Sixty-two patients responded to treatment and achieved complete remission (CR) following induction therapy (25 ALL and 37 AML patients) while 25 patients were nonresponders. As shown in Fig. 2, the percentages of circulating Th17 cells were reduced significantly in ALL (Fig. 2a) and AML (Fig. 2b) responders (2.25 $\pm 0.44 \%$, $1.63 \pm 0.27 \%$, respectively) compared with the same patients before treatment $(2.88 \pm 0.65 \%, 3.09 \pm 0.55 \%)$. Interestingly, significantly higher pretreatment levels of Th17 cells were observed in responders $(3.032 \pm 0.58 \%)$ when compared to non-responders $(2.53 \pm 0.49 \%)$ in the whole group of acute leukemia patients $(P<0.0001)$ (Fig. 3). Moreover, low levels of Th17 cells (1.95 and $2.23 \%$ ) were observed in the two patients who were not eligible for chemotherapy and received supportive care only.

Increased serum concentrations of IL-17 and IL-21 in acute leukemia patients

The IL-17 and IL-21 serum concentrations showed statistically significant higher levels in acute leukemia patients

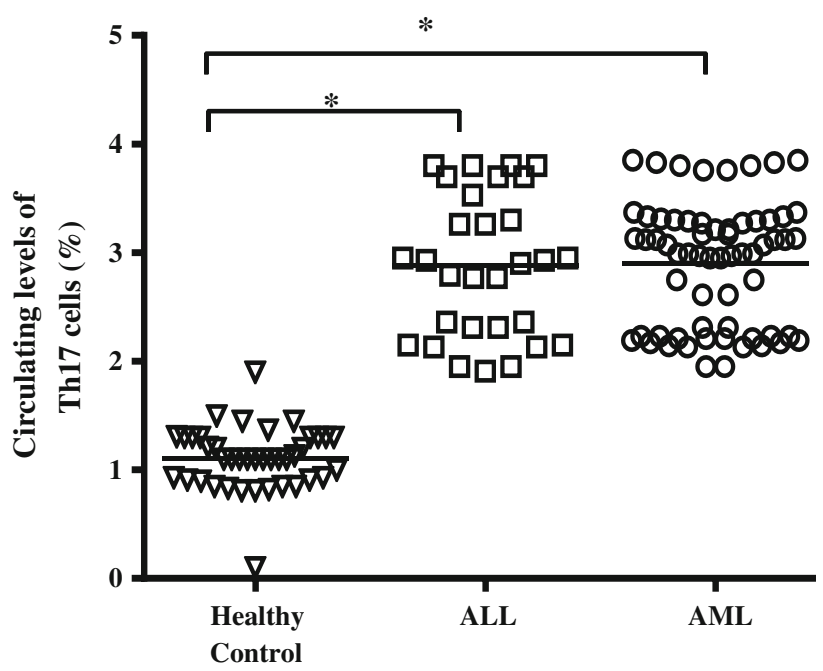

Fig. 1 Increased levels of circulating Th17 cells in untreated patients with ALL and AML compared to healthy controls 

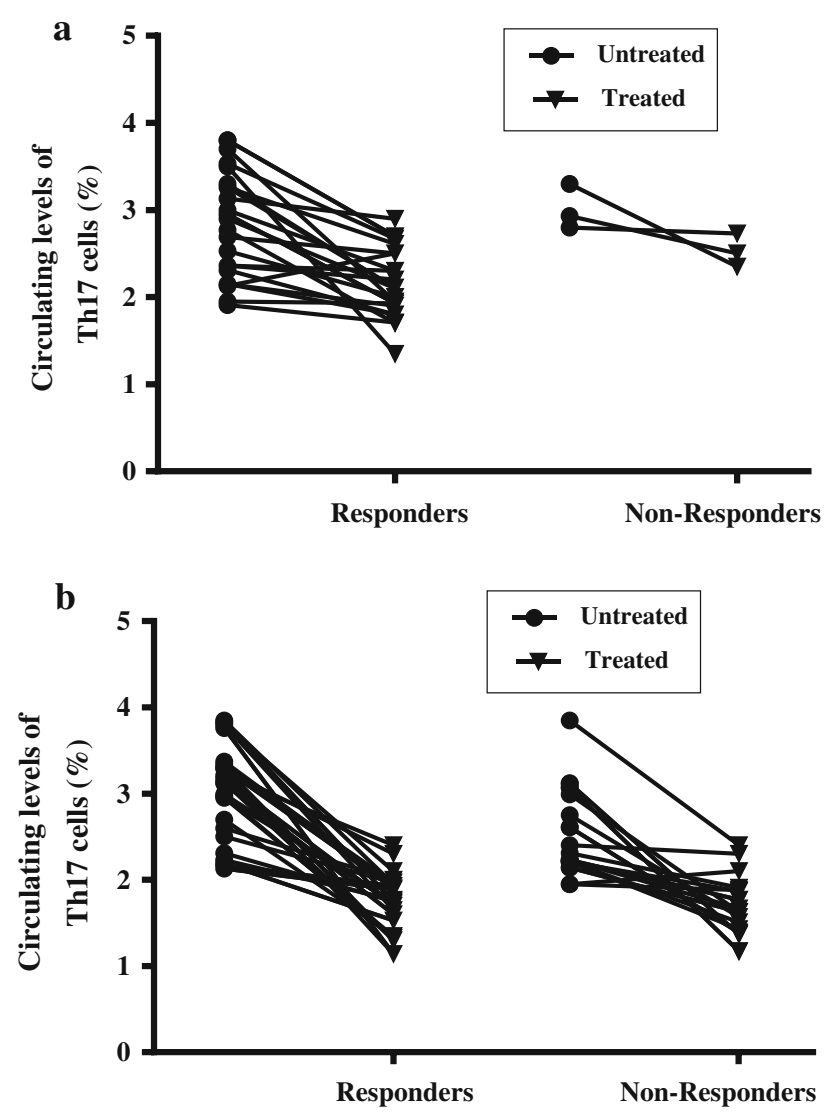

Fig. 2 Comparison of circulating Th17 cells in ALL (a) and AML (b) patients before and after chemotherapy. Th17 cells were reduced significantly in responders compared to their levels before treatment

compared to healthy volunteers $(P<0.0001$ for IL-17 and IL-21, respectively, for both ALL and AML) (Table 2). There was no significant difference regarding IL-17 concentration between ALL and AML patients. However, ALL patients showed statistically significant higher serum concentrations of IL-21 than AML patients $(P=0.002)$. Additionally, serum concentrations of IL-17 and IL-21 showed positive correlation with circulating Th17 cells in both ALL ( $r=0.768, P<0.0001, r=0.548, P<0.0001$ for IL-17 and IL-21, respectively) and AML patients ( $r=0.897, P<0.0001, r=0.765, P<0.0001$ for IL-17 and IL-21, respectively).

Circulating Th17 cells and overall survival (OS) in acute leukemia patients

Patients were dichotomized into two groups according to the median level of circulating Th17 cells (median $=2.91$ and $2.99 \%$ for ALL and AML, respectively). Group 1 included patients with Th17 cells above the median level (Th17 ${ }^{\text {High }} ; n=15$ and 32 ALL and AML patients, respectively), and group 2 included patients with Th17 cells lower than the median level (Th17 ${ }^{\text {low }} ; n=15$ and 31

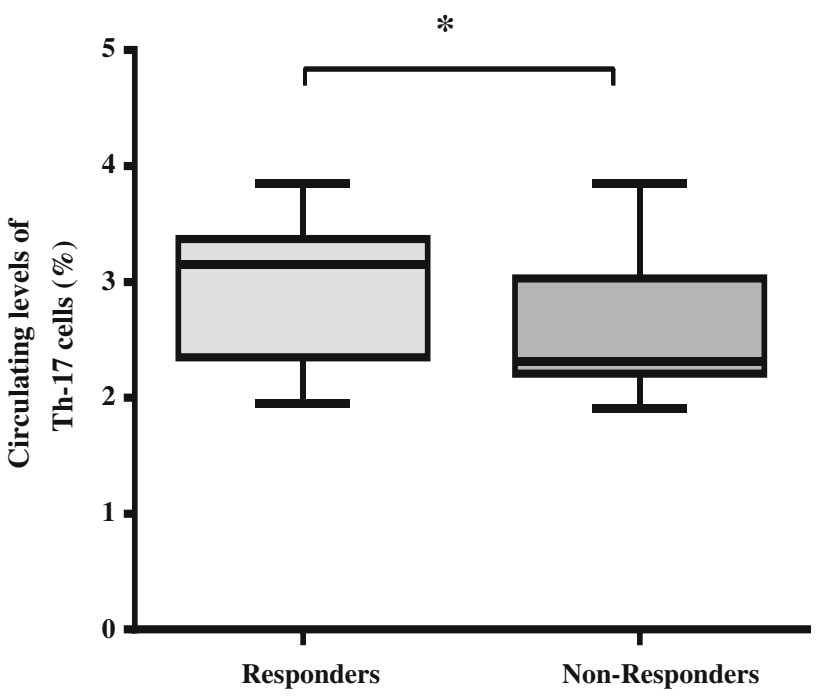

Fig. 3 Increased pretreatment levels of circulating $T$ helper17(Th17) cells in responders $(n=62)$ compared to non-responders $(n=25)$ of acute leukemia patients. All results are presented as mean (horizontal line). Minimum and maximum (boxes) and variation range (whiskers)

ALL and AML patients, respectively). Survival analysis was performed and, as depicted in Fig. 4a, b, in group 1 patients, the median overall survival was longer than in group 2 (16.6 vs. 11 months in ALL, $P=0.029 ; 13.9$ vs. 8.3 months in AML, $P=0.027$ ).

Circulating Th17 cells as a significant independent positive prognostic factor in acute leukemia

Despite the heterogeneity of our patients, univariate analysis identified age $(P=0.008)$, WBCs $(P=0.034)$, IL-21 $(P=0.005)$, IL-17 $(P=0.014)$, in addition to Th17 level $(P=0.029)$ as predictors for OS in patients with ALL. In patients with AML, Th17 level $(P=$ 0.027), WBCs $(P=0.041)$, age $(P=0.038)$, adverse cytogenetic abnormalities $(P=0.001)$ and IL-17 $(P=$ $0.035)$ were all significant factors. When these prognostic factors were considered in a multivariate analysis, Th17cells and IL-17 serum level merged as significant independent positive prognostic factors for OS. Age and IL-21 maintained their discriminating power as poor prognostic factors in ALL. In AML, adverse cytogenetic abnormalities remained significant negative predictor for survival (Table 3 ).

\section{Discussion}

The magnitude of the data regarding Th17 cells in experimental tumor models and cancer patients suggests that the role of Th17 cells in tumor immunity is highly complex, 
Table 2 Concentration of IL-17 and IL-21 serum levels among acute leukemia patients compared to healthy controls

\begin{tabular}{llccrr}
\hline & Healthy control $(n=40)$ & ALL $(n=30)$ & AML $(n=63)$ & One-way ANOVA & Post hoc tests \\
\hline IL-17 $(\mathrm{pg} / \mathrm{mL})$ & $12.89 \pm 4.9$ & $43.2 \pm 13.5$ & $40.78 \pm 15.30$ & $P=0.0001$ & $(1)$ versus $(2)=0.0001$ \\
& & & & $(1)$ versus $(3)=0.0001$ \\
& & & $(2)$ versus $(3)=0.393$ \\
$\mathrm{IL}-21(\mathrm{pg} / \mathrm{mL})$ & $252.8 \pm 45.1$ & $1257.5 \pm 718.2$ & $944.3 \pm 394.3$ & $P=0.0001$ & $(1)$ versus $(2)=0.0001$ \\
& & & & $(1)$ versus $(3)=0.0001$ \\
& & & $(2)$ versus $(3)=0.002$ \\
\hline
\end{tabular}

a

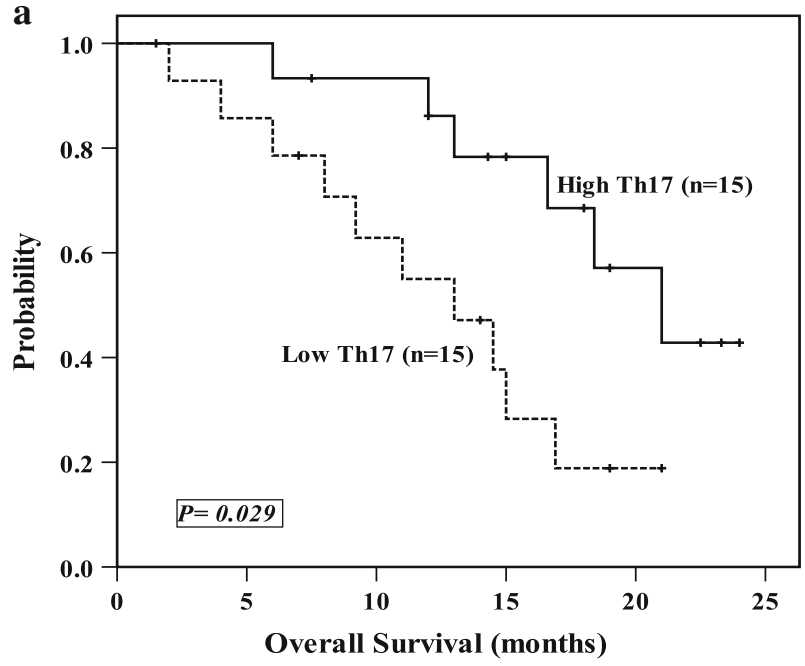

b

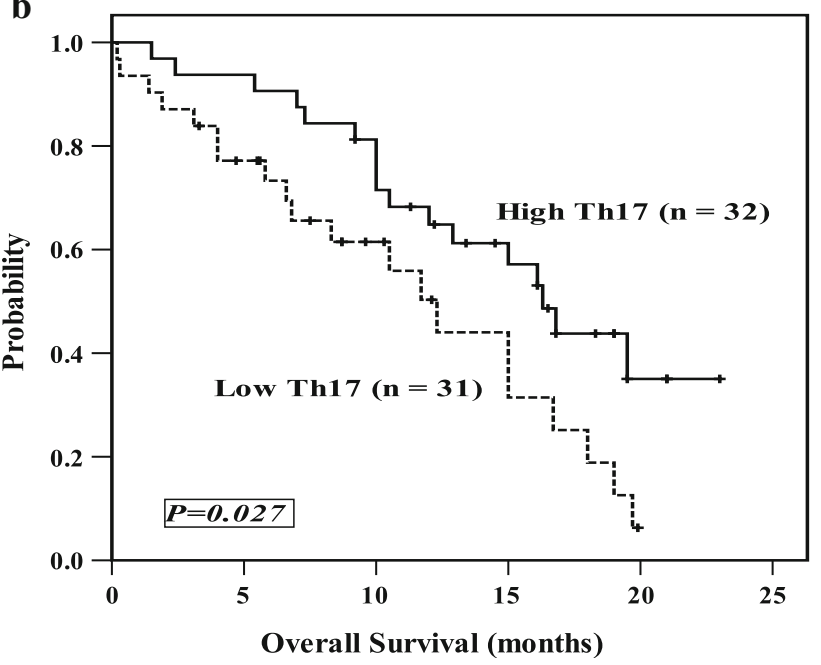

Fig. 4 Kaplan-Meier plot comparing OS based on the median level of circulating Th17 cells in ALL (a) and AML patients (b)

and it remains controversial whether these cells promote tumor growth or regulate anti-tumor responses [21]. Further complicating the matter are occasionally conflicting results of studies and contradictory data about the role of Th17 in patients with acute leukemia [17, 18, 22].

In our study, we analyzed the distribution of Th17 cells in the peripheral blood of acute leukemia patients and showed that the pretreatment level of Th17 cells was higher in patients than in healthy volunteers and in patients with favorable response to induction therapy than nonresponders. Muranski et al. [23] found that tumor-specific Th17-polarized cells could eradicate large established melanomas in mice. That is, Th17 cells exerted an antitumor effect, which was also proved in other solid tumors $[7,24,25]$. In light of these results, elevation in Th17 cells in our acute leukemia patients may be explained as a protective reaction of the immune system in certain stages of the disease.

We have further demonstrated that the increased circulating Th17 cells in untreated patients were reduced when those patients achieved CR after chemotherapy, suggesting that circulating Th17 cells are related to tumor burden and could be valuable for monitoring response to chemotherapy in acute leukemia patients. A previous study has also described increased frequencies of circulating Th17 cells in patients with untreated AML with normalization when patients achieved complete remission after chemotherapy [17]. Interestingly, elevated levels of Th17 cells have been also found in patients with favorable response to therapy in some tumors [26]. In contrast to our results, Ersvaer et al. [18] have demonstrated normal Th17 levels for patients with untreated AML which did not differ from healthy controls. However, controls in that study were younger than untreated patients. Before statistical comparisons and if any age-dependent difference among the controls was detected, Ersvaer and his colleagues used to compare untreated patients with those controls being above 50 years of age $(n=15)$, which may be not adequate to show a difference between AML patients and controls.

IL-17 is the hallmark effector cytokine produced by Th17 cells [16]. The biological function of Th17 cells is closely associated with its secreted IL-17 [18]. Among Th17-associated cytokines, IL-21 appears to promote Th17 differentiation and serves as an autocrine regulator of IL-17 production [15]. Using ELISA, we found that serum levels of IL-17 and IL-21 in untreated acute leukemia patients were significantly higher than in controls and correlated positively with levels of circulating Th17 cells. Therefore, we believe that tumor-associated Th17 cells have the 
Table 3 Multivariate Cox proportional hazard model of overall survival in acute leukemia patients

\begin{tabular}{|c|c|c|c|c|c|c|c|c|c|}
\hline \multirow[t]{3}{*}{ Variables } & \multicolumn{4}{|c|}{ ALL } & \multirow[t]{3}{*}{ Variables } & \multicolumn{4}{|c|}{ AML } \\
\hline & \multirow[t]{2}{*}{ OR } & \multicolumn{2}{|c|}{$95 \% \mathrm{CI}$} & \multirow[t]{2}{*}{$P$} & & \multirow[t]{2}{*}{ OR } & \multicolumn{2}{|c|}{$95 \% \mathrm{CI}$} & \multirow[t]{2}{*}{$P$} \\
\hline & & Lower & Upper & & & & Lower & Upper & \\
\hline High Th17 (\%) & 0.273 & 0.09 & 0.829 & 0.02 & High Th17 (\%) & 0.489 & 0.254 & 0.941 & 0.032 \\
\hline High IL-17 (pg/mL) & 0.406 & 0.112 & 1.467 & 0.16 & High IL-17 (pg/mL) & 0.522 & 0.263 & 1.034 & 0.062 \\
\hline WBCs $\left(>50 \times 10^{9} / \mathrm{L}\right)$ & 2.916 & 0.821 & 10.353 & 0.09 & WBCs $\left(>50 \times 10^{9} / \mathrm{L}\right)$ & 1.922 & 0.990 & 3.733 & 0.054 \\
\hline Age >35 (years) & 4.001 & 1.267 & 12.63 & 0.01 & Adverse cytogenetics & 2.711 & 1.393 & 5.275 & 0.003 \\
\hline
\end{tabular}

ability to influence immune responses and produce antitumor effect through the action of any one or a combination of their related cytokines.

In regard to survival, we documented, for the first time, a positive correlation between circulating Th17 cells and survival in this group of acute leukemia patients. Even after controlling for other prognostic factors, Th17 cells remained a negative predictor of death hazard, suggesting that Th17 cells exert direct or indirect anti-tumor effect in acute leukemia and may be a prognostic indicator for this group of patients.

Lastly, we assessed the correlation between serum IL-17 level and the prognosis of the same group of patients. As might be expected, higher IL-17 serum level was also correlated with longer survival, which is consistent with previous demonstration that IL-17 and IL-6 and IL-1 $\beta$, which promote human Th17 cell differentiation, are members of clusters of cytokines that correlate with better prognosis in CLL [27].

Of note, elevated levels of Th17 cells have also been reported in CLL patients and were proved to favorably modify the clinical course of this group of patients, regardless of prognostic or genetic subgroup [28]. Along this line, Kryczek et al. [7] have detected that levels of Th17 cells were lower in the ascites of advanced ovarian cancer patients, which may have positive effect on prognosis of patients. Hence, their data provide evidence that Th17 cells may contribute to protective tumor immunity in humans with advanced tumors. In contrast, our results were discrepant with previous data on pancreatic cancer, which revealed that median survival time was shorter in patients with high level of Th17 cells [29]. However, this discrepancy may be due to the different biological characteristics among different tumor types [11], and the possibility that the function of Th17 cells may vary according to different cancer cause, type, and location, as well as stage of cancer.

Demonstration of the effect of IL-21 in acute leukemia cell lines and acute leukemia patients remains unproven. Previously published reports indicated that IL-21, secreted by Th17 cells, promotes fludarabine- and rituximab-mediated direct apoptosis of CLL cells [30]. Brenne et al. [31] found that IL-21 induced proliferation and inhibited apoptosis in the IL-6-dependent human myeloma cell lines. In AML, Li et al. [16] detected the IL-21 levels in plasma samples taken from 24 AML patients before chemotherapy, 20 AML patients with CR, and 30 health adults, and found no significant differences between groups. Our results detected positive correlation between IL-21 and survival in ALL, which raise the possibility that IL-21 has anti-leukemic effect in this group of patients. In contrast, we failed to prove correlation between pretreatment IL-21 serum level and survival in AML. We further identified significantly elevated serum IL-21 levels in ALL than AML patients. Therefore, we assume that $\mathrm{T}$ cell immune reaction to leukemia appears to be much higher in ALL than in AML. However, more research on large number of patients will be needed to confirm these data.

In conclusion, we explored Th17 cells in acute leukemia patients, as a valuable marker for monitoring patients after chemotherapy, and documented their association with a more favorable outcome. Our data provides clinical evidence linking Th17 cells to immune protection in acute leukemia and opens a new avenue in the study of tumor immunotherapy based on promoting Th17 cell population.

Conflict of interest No potential conflicts of interest relevant to this article were reported.

Open Access This article is distributed under the terms of the Creative Commons Attribution License which permits any use, distribution, and reproduction in any medium, provided the original author(s) and the source are credited.

\section{References}

1. Koebel CM, Vermi W, Swann JB, Zerafa N, Rodig SJ, Old LJ, Smyth MJ, Schreiber RD. Adaptive immunity maintains occult cancer in an equilibrium state. Nature. 2007;450:903-7.

2. Finn OJ. Cancer immunology. N Engl J Med. 2008;358:2704-15.

3. Galon J, Costes A, Sanchez-Cabo F, Kirilovsky A, Mlecnik B, Lagorce-Pagès C, Tosolini M, Camus M, Berger A, Wind P, Zinzindohoue F, Bruneval P, Cugnenc P, Trajanoski Z, Fridman W, Pagès F. Type, density, and location of immune cells within human colorectal tumors predict clinical outcome. Science. 2006;313:1960-4. 
4. Zhang L, Conejo-Garcia JR, Katsaros D, Gimotty PA, Massobrio M, Regnani G, Makrigiannakis A, Gray H, Schlienger K, Liebman MN, Rubin SC, Coukos G. Intratumoral T cells, recurrence, and survival in epithelial ovarian cancer. $\mathrm{N}$ Engl $\mathrm{J}$ Med. 2003;348:203-13.

5. Sato E, Olson SH, Ahn J, Bundy B, Nishikawa H, Qian F, Jungbluth AA, Frosina D, Gnjatic S, Ambrosone C, Kepner J, Odunsi T, Ritter G, Lele S, Chen YT, Ohtani H, Old LJ, Odunsi $\mathrm{K}$. Intraepithelial CD8+ tumor-infiltrating lymphocytes and a high $\mathrm{CD} 8+/$ regulatory $\mathrm{T}$ cell ratio are associated with favorable prognosis in ovarian cancer. Proc Natl Acad Sci USA. 2005; 102:18538-43.

6. Curiel TJ, Coukos G, Zou L, Alvarez X, Cheng P, Mottram P, Evdemon-Hogan M, Conejo-Garcia JR, Zhang L, Burow M, Zhu Y, Wei S, Kryczek I, Daniel B, Gordon A, Myers L, Lackner A, Disis ML, Knutson KL, Chen L, Zou W. Specific recruitment of regulatory $\mathrm{T}$ cells in ovarian carcinoma fosters immune privilege and predicts reduced survival. Nat Med. 2004;10:942-9.

7. Kryczek I, Banerjee M, Cheng P, Vatan L, Szeliga W, Wei S, Huang E, Finlayson E, Simeone D, Welling TH, Chang A, Coukos G, Liu R, Zou W. Phenotype, distribution, generation, and functional and clinical relevance of Th17 cells in the human tumor environments. Blood. 2009;6(114):1141-9.

8. Dong C. TH17 cells in development: an updated view of their molecular identity and genetic programming. Nat Rev Immunol. 2008;8:337-48.

9. Bettelli E, Korn T, Kuchroo VK. Th17: the third member of the effector T cell trilogy. Curr Opin Immunol. 2007;19:652-7.

10. Ersvaer E, Melve GK, Bruserud O. Future perspectives: should Th17 cells be considered as a possible therapeutic target in acute myeloid leukemia patients receiving allogeneic stem cell transplantation? Cancer Immunol Immunother. 2011;60:1669-81.

11. Kryczek I, Wei S, Zou L, Altuwaijri S, Szeliga W, Kolls J, Chang A, Zou W. Cutting edge: Th17 and regulatory T cell dynamics and the regulation by IL-2 in the tumor microenvironment. J Immunol. 2007;178:6730-3.

12. Murugaiyan G, Saha B. Protumor vs antitumor functions of IL17. J Immunol. 2009;183:4169-75.

13. Kryczek I, Wei S, Szeliga W, Vatan L, Zou W. Endogenous IL17 contributes to reduced tumor growth and metastasis. Blood. 2009;114:357-9.

14. Korn T, Bettelli E, Gao W, Awasthi A, Jager A, Strom TB, Oukka M, Kuchroo VK. IL-21 initiates an alternative pathway to induce proinflammatory $\mathrm{T}(\mathrm{H}) 17$ cells. Nature. 2007;448:484-7.

15. Nurieva R, Yang XO, Martinez G, Zhang Y, Panopoulos AD, Ma L, Schluns K, Tian Q, Watowich SS, Jetten AM, Dong C. Essential autocrine regulation by IL-21 in the generation of inflammatory T cells. Nature. 2007;448:480-3.

16. Li P, Ji M, Park J, Bunting KD, Ji C, Tse W. Th17 related cytokines in acute myeloid leukemia. Front Biosci. 2012;17:2284-94.

17. Wu C, Wang S, Wang F, Chen Q, Peng S, Zhang Y, Qian J, Jin J, $\mathrm{Xu} \mathrm{H}$. Increased frequencies of $\mathrm{T}$ helper type 17 cells in the peripheral blood of patients with acute myeloid leukaemia. Clin Exp Immunol. 2009;158:199-204.

18. Ersvaer E, Liseth K, Skavland J, Gjertsen BT, Bruserud O. Intensive chemotherapy for acute myeloid leukemia differentially affects circulating TC1, TH1, TH17 and TREG cells. BMC Immunol. 2010;9:11-38.

19. Swerdlow SH, Campo E, Harris NL, Jaffe ES, Pileri SA, Stein H, Thiele J, Vardiman JW, editors. WHO classification of tumors of haematopoietic and lymphoid tissue. 4th ed. Lyon: IARC; 2008.

20. Luo X, Tan H, Zhou Y, Xiao T, Wang C, Li Y. Notch1 signaling is involved in regulating Foxp3 expression in T-ALL. Cancer Cell Int. 2013;13:34.

21. Ji Y, Zhang W. Th17 cells: positive or negative role in tumor. Cancer Immunol Immunother. 2010;59:979-87.

22. Su MF, Wang CF, Zhao YM, Wu JX, Zhang Y. Expression and clinical significance of IL-17 and IL-21 in patients with acute leukemia. Zhongguo Shi Yan Xue Ye Xue Za Zhi. 2010;18: 1143-6.

23. Muranski P, Boni A, Antony PA, Cassard L, Irvine KR, Kaiser A, Paulos CM, Palmer DC, Touloukian CE, Ptak K, Gattinoni L, Wrzesinski C, Hinrichs CS, Kerstann KW, Feigenbaum L, Chan CC. Restifo NP Tumor-specific Th17-polarized cells eradicate large established melanoma. Blood. 2008;112:362-73.

24. Gnerlich JL, Mitchem JB, Weir JS, Sankpal NV, Kashiwagi H, Belt BA, Porembka MR, Herndon JM, Eberlein TJ, Goedegebuure $\mathrm{P}$, et al. Induction of Th17 cells in the tumor microenvironment improves survival in a murine model of pancreatic cancer. J Immunol. 2010;185:4063-71.

25. Yamamoto M, Kamigaki T, Yamashita K, Hori Y, Hasegawa H, Kuroda D, Moriyama H, Nagata M, Ku Y, Kuroda Y. Enhancement of anti-tumor immunity by high levels of Th1 and Th17 with a combination of dendritic cell fusion hybrids and regulatory $\mathrm{T}$ cell depletion in pancreatic cancer. Oncol Rep. 2009;22:337-43.

26. Zou W, Restifo NP. T(H)17 cells in tumour immunity and immunotherapy. Nat Rev Immunol. 2010;10:248-56.

27. Yan XJ, Li W, Yancopoulos S, Dozmorov I, Centola M, Allen SL, Rai KR, Chiorazzi N, Sherry B. Identification of distinct cytokine and chemokine clusters that correlate with outcome in B-cell chronic lymphocytic leukemia: implications for disease pathogenesis. Blood. 2010;116:1368.

28. Jain P, Javdan M, Feger FK, Chiu PY, Sison C, Damle RN, Bhuiya TA, Sen F, Abruzzo LV, Burger JA, Rosenwald A, Allen SL, Kolitz JE, Rai KR, Chiorazzi N, Sherry B. Th17 and nonTh17 interleukin-17-expressing cells in chronic lymphocytic leukemia: delineation, distribution, and clinical relevance. Haematologica. 2012;97:599-607.

29. He S, Fei M, Wu Y, Zheng D, Wan D, Wang L, Li D. Distribution and clinical significance of th17 cells in the tumor microenvironment and peripheral blood of pancreatic cancer patients. Int J Mol Sci. 2011;12:7424-37.

30. Gowda A, Roda J, Hussain SR, Ramanunni A, Joshi T, Schmidt S, Zhang X, Lehman A, Jarjoura D, Carson WE, Kindsvogel W, Cheney C, Caligiuri MA, Tridandapani S, Muthusamy N, Byrd JC. IL-21 mediates apoptosis through up-regulation of the BH3 family member BIM and enhances both direct and antibodydependent cellular cytotoxicity in primary chronic lymphocytic leukemia cells in vitro. Blood. 2008;1:4723-30.

31. Brenne AT, Baade Ro T, Waage A, Sundan A, Borset M, HjorthHansen H. Interleukin-21 is a growth and survival factor for human myeloma cells. Blood. 2002;99:3756-62. 